\title{
Narrativa ensaística rizomática: fios da memória do Frankenstein pós-moderno ${ }^{1}$

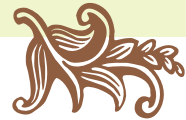

Ensaio: Gênero de discurso cujo aparecimento na cultuClaudiana Soerensen ${ }^{2}$ [Et Al. ra ocidental tem como marco consagrado a publicação, em 1580, do livro do pensador francês Michel de Montaigne (1533-1592), justamente intitulado Ensaios. Nele foram reunidos textos quase sempre bastante curtos e fragmentários, aparentemente desconectados, sobre temas os mais díspares (...). Justificando essa disparidade e servindo de fio condutor do livro, está uma curiosidade assumidamente despretensiosa, que privilegia a inquietude sobre a certeza, o problema sobre o sistema, a sugestão e a expressividade sobre a clareza assertiva. Através desse movimento discursivo, Montaigne encena o próprio movimento do pensamento a se constituir, de modo ao mesmo tempo precário e complexo, a partir de experiências individuais de ordem existencial e intelectual, anteriormente a qualquer formalização teórica e disciplinar. "Eu sei por experiência", nos esclarece ele, além de alertar sobre a pouca importância de seus escritos, que versariam apenas sobre ele mesmo e seus interesses, sem nenhuma aspiração ao universal e à posteridade.

ABsTRACT:

\section{Com licença poética}

Quando nasci um anjo esbelto, desses que tocam trombeta, anunciou:

vai carregar bandeira.

Cargo muito pesado pra mulher, esta espécie ainda envergonhada.

Aceito os subterfúgios que me cabem,

sem precisar mentir.

Não sou feia que não possa casar, acho o Rio de Janeiro uma beleza e

ora sim, ora não, creio em parto sem dor.

Mas o que sinto escrevo. Cumpro a sina.

Inauguro linhagens, fundo reinos

- dor não é amargura.

Minha tristeza não tem pedigree,

já a minha vontade de alegria,

sua raiz vai ao meu mil avô.

Vai ser coxo na vida é maldição pra homem.

Mulher é desdobrável. Eu sou.

\section{- QUE? LAVAR SEM SABÃO? \\ Sim! A alvura que só OMO dá torna o sabão antiquado!}

\begin{abstract}
REsumO: Os textos a seguir são construtos de décadas e, provisoriamente, fazem parte do recorte aqui proposto. O presente ensaio tem o intuito de trazer à baila noções e conceitos da teoria e da crítica literária, propondo o "nascimento do leitor e a morte do autor" e a "desconstrução" da leitura linear.

PAlavRAS-CHAVE: Clarice Lispector, Cíntia Moscovich, Valêncio Xavier, Roland Barthes.
\end{abstract}

ulher é desdobravel. Eu sou.

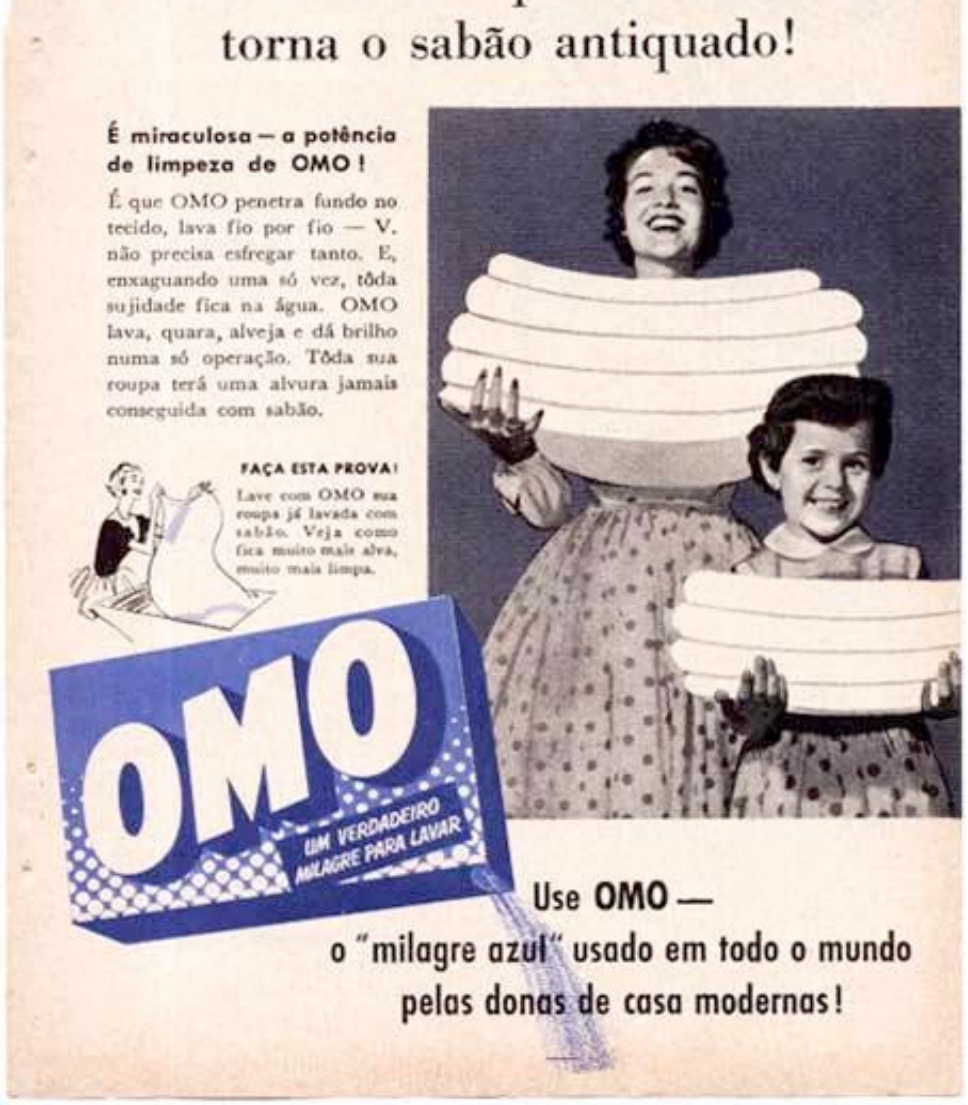


A cordialidade, a abertura, a polêmica são marcas da escritura ensaística que revelam o tipo de força deflagrada por sua despretensão - despretensão manifestada também sem sua relação com aquilo que se propõe conhecer. De fato, ela tem como sua segunda premissa a impotência para produzir ou para descobrir algo absolutamente original, como propõem a arte e a ciência. Pois interpretar significa aí apenas reordenar o já-existente, hiper-interpretar o que já foi objeto de interpretações anteriores, iluminado, segundo Theodor Adorno, a pletora de significações encasulada em cada fenômeno cultural. Face a ela, cabe reconhecer a impossibilidade de um saber pleno resignar-se ao parcial e ao fragmentado que, paradoxalmente, revela, em sua plenitude, o insólito das coisas, a fluente realidade da vida em seu caráter humano e histórico, libertada da imobilidade que Ihe impõem as ideias de origem, natureza e verdade.

Esta história poderia chamar-se "As estátuas". Outro nome possível é "O assassinato". E também "Como matar baratas". Farei então pelo menos três histórias, verdadeiras porque nenhuma delas mente a outra. Embora uma única, seriam mil e uma, se mil e uma noites me dessem.

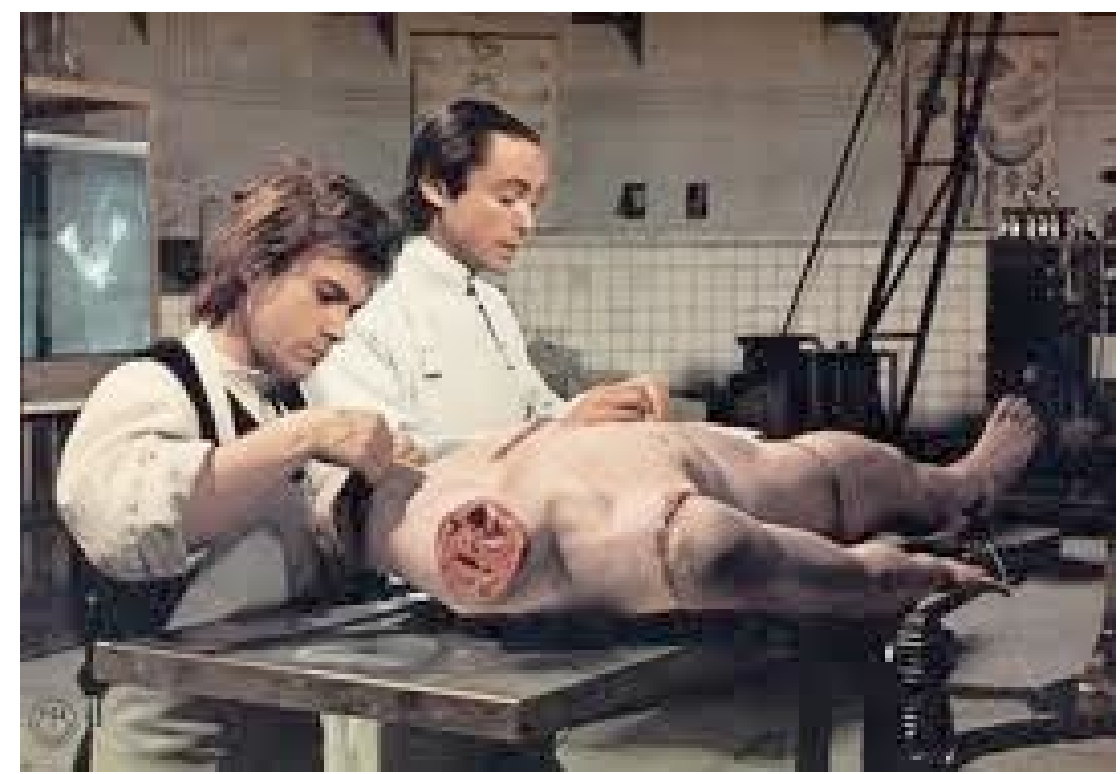

"Ela apaziguara tão bem a vida, cuidara tanto para que esta não explodisse."

Clarice Lispector

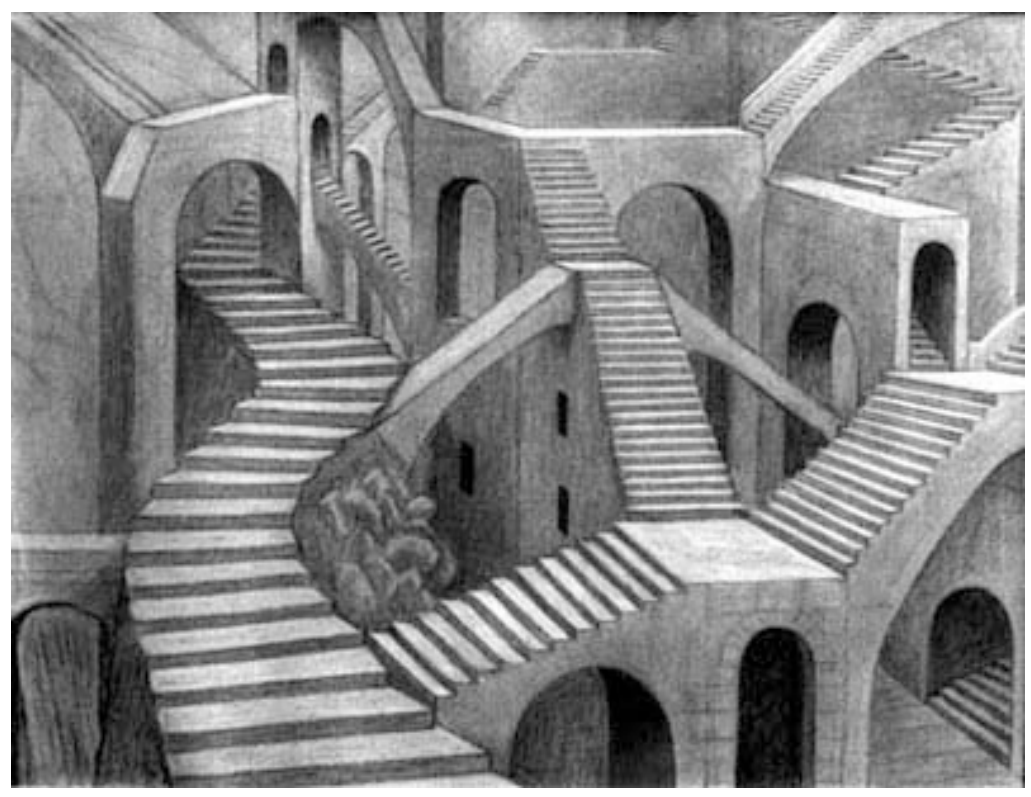

A coisa narrada é mergulhada na vida do narrador e dali retirada; [...] é vista com objetividade pelo narrador, embora este confesse tê-la extraído da sua vivência. (SANTIAGO, 1989, p. 40) 
Em meados do século 19, não muito após Leopold von Ranke (1795-1886) proclamar o ideal da história profissional, a história objetiva baseada em documentos oficiais preservados em arquivos, Jacob Burckhardt publicou seu livro sobre A civilização do Renascimento na Itália. O subtítulo do livro era curto, mas expressivo: "Um ensaio" ("ein Versuch"). Ele deixou bem claras as razões para escolher esse subtítulo na introdução do livro, que começa com a frase: "Essa obra leva o título de mero ensaio no sentido estrito da palavra", e prossegue sustentando que "a cada olho, talvez, os contornos de uma dada civilização apresentam uma figura diversa" e que "os mesmos estudos que serviram a esse trabalho podem facilmente, em outras mãos (...), conduzir a conclusões essencialmente diversas".

O olhar humano pós-moderno é desejo e palavra que caminham pela imobilidade, vontade que admira e se retrai inútil, atração por um corpo que, no entanto, se sente alheio à atração, energia própria que se alimenta vicariamente de fonte alheia. Ele é o resultado crítico da maioria das nossas horas de vida cotidiana. (SANTIAGO, 1989, P. 48)
A senhora talvez saiba, Dona Eugênia, que a esta hora todas as mulheres estão cortando cebolas. Todas. Até a judia do lado, a das ancas largas e da casa pintada daquele amarelinho (não que a senhora tenha inveja, isso nunca, bem sei), pois é, também a mulher judia, que tem duas empregadas na casa, também ela está cortando cebolas.

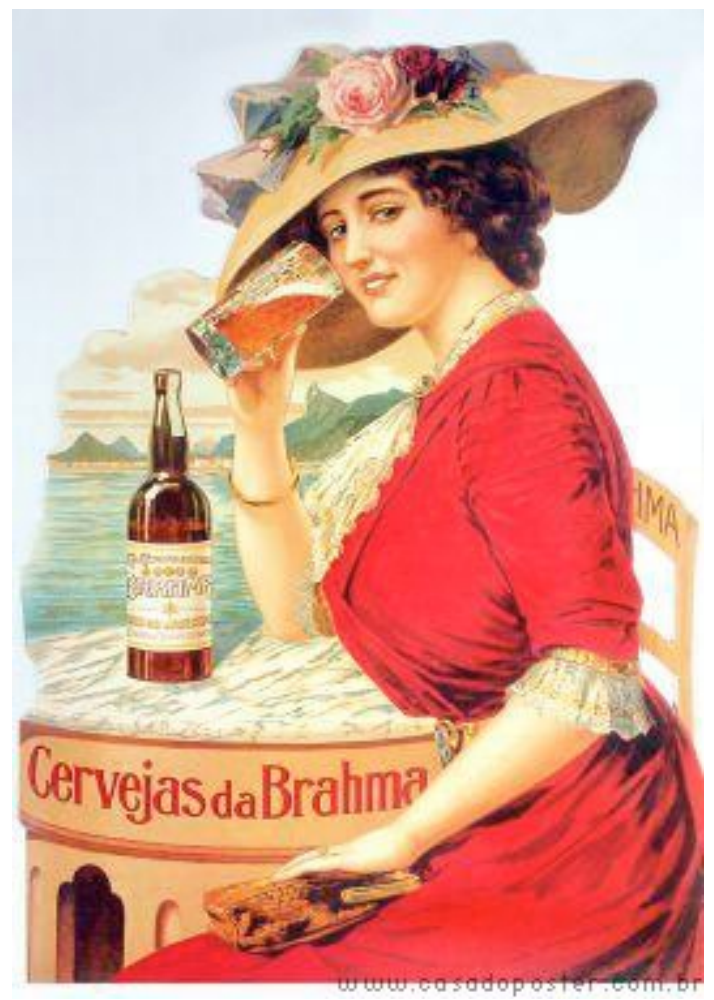

\section{"A memória, onde cresce a his- tória, que por sua vez a alimenta, procura salvar o passado para servir o presente e o futuro". (LE GOFF, 1992, p. 477}

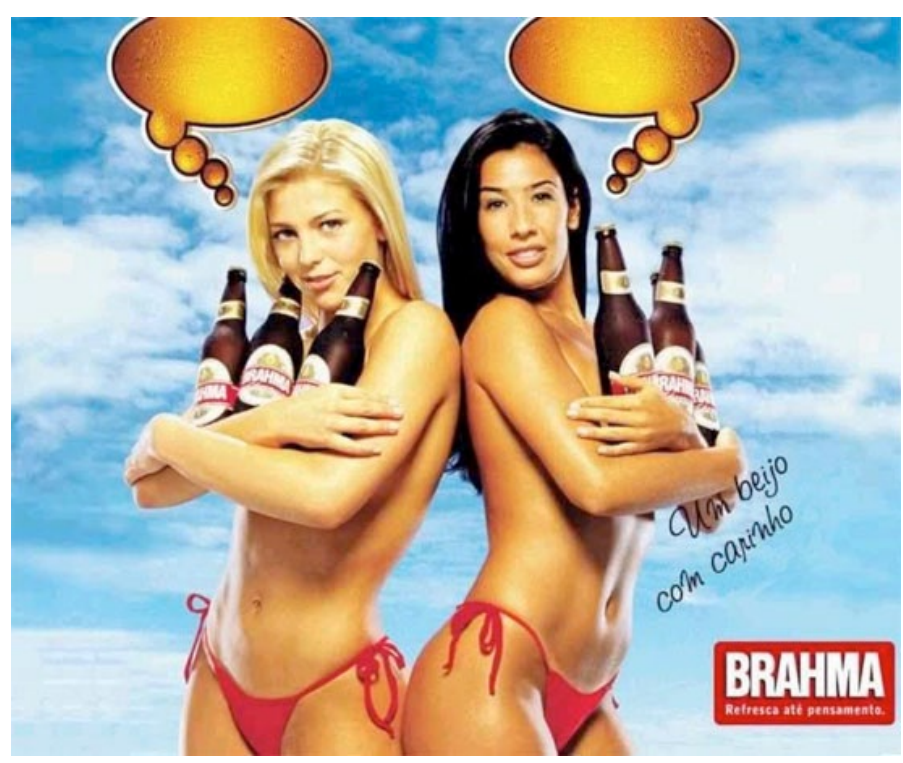


Primeiro descascando, depois dividindo ao meio, depois talhando ao comprido, depois passando a faca rente aos dedos, perigosamente rente, para conseguir os pedacinhos cúbicos, miúdos e parelhos.

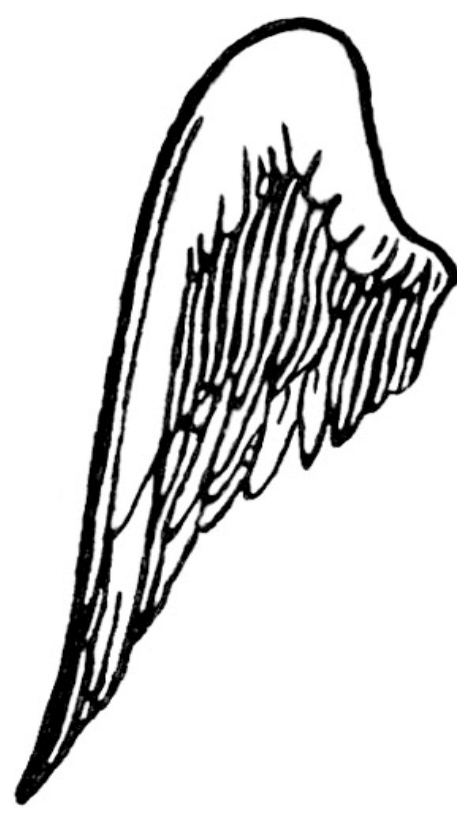
esturricaria o de-dentro
Assim fiz. Morreram.
Hipotrélico: "antipodático, sengraçante imprizido; ou talvez, vice-dito: indivíduo pedante, importuno agudo, falta de respeito para com a opinião alheia" (Tutaméia.p.76)

Em "A literatura e a vida", parte integrante da obra Crítica e clínica, o filósofo francês Gilles Deleuze (1997, p.14) afirma que "o escritor é um homem que viu e ouviu coisas demasiado grandes, fortes, irrespiráveis, e regressa de olhos vermeIhos e com os tímpanos perfurados"

Todas no mesmo exercício, Dona Eugênia, todas chorando lágrimas ácidas para o bem do arroz ou do refogado ou da carne. Todas pelo bem da comida, a que sempre tiveram de forjar dos sucos do próprio corpo, da habilidade das próprias mãos. Da teta ao fogão. Sempre.

Todo o artista aspira a ser lido. Não existe correspondência particular de um artista que consideramos 'experimental' [...] que não mostre como aquele autor, mesmo quando sabia que ia contra o horizonte de expectativas do seu próprio leitor comum e atual, aspirava a formar um futuro leitor particular, capaz de entendê-lo e de saboreálo, sinal de que estava orquestrando a sua obra como sistema de instruções para um Leitor Modelo que estivesse em condições de compreendê-lo apreciá-lo e amálo. Não existe nenhum autor que deseje ser ilegível ou ignorável. (ECO, 1989, p. 100)

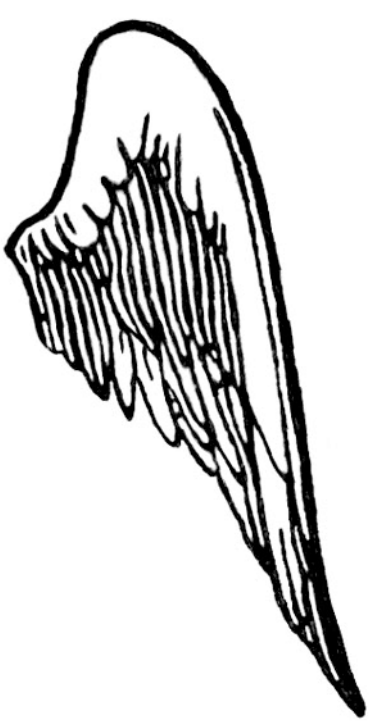




\section{Ela voltou deslumbrada!}

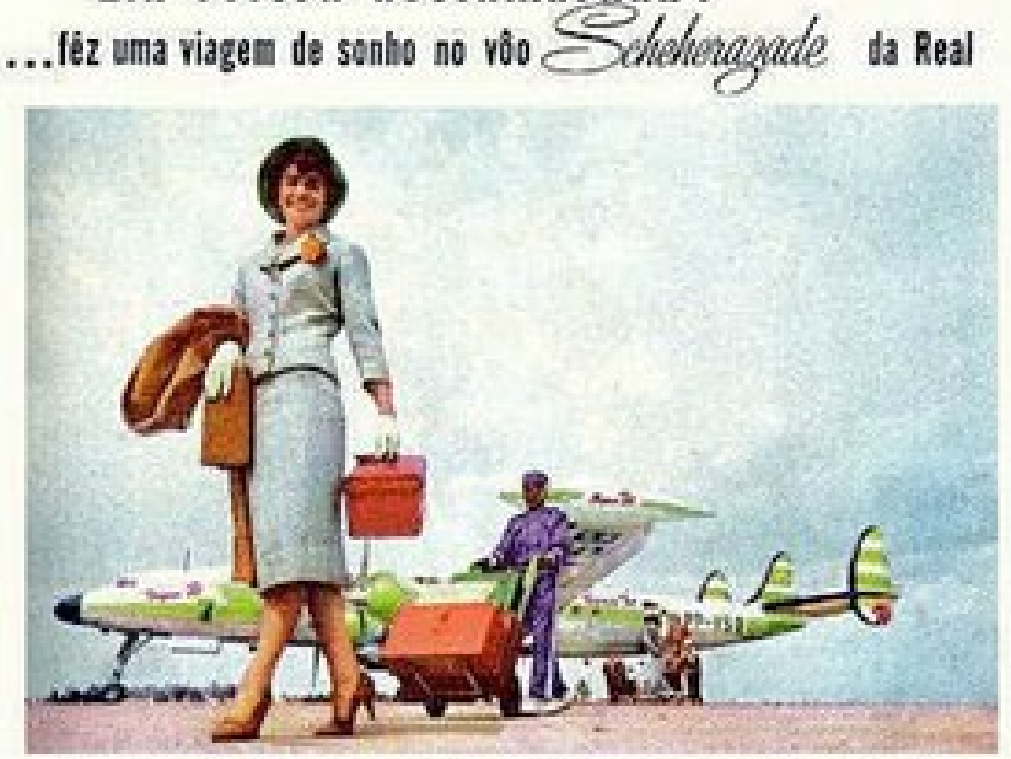

Ha fok aos Eutados Unibos. Via crandes e maravithocas cidades. Vi.

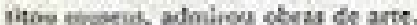
Creapres. E volion KClin Ristre or memoriai eve ruardark derta ex.

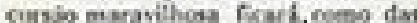
muin leckectiveis, a tiespla vistem em sh, o it $e$ volur no vo Seluthe rarade da Real. Pernes a va Sulbertuale $t$ ine verdudeiro der.

Bumbramence. Save, seress, ceafortherl. An horas voarm mali do que - probrio avilio rapidfulimo, lat Saper-H Contellation, que itm at condiclonado poltroeas macilar.

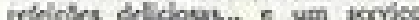
impocivel. A alogria de fr aos Fittados Unidos \& muito maber, goando ve voa pelo Sepre-H Constellatioa da keal

Voe também aos Estados Unidos \& à Argentina pelo
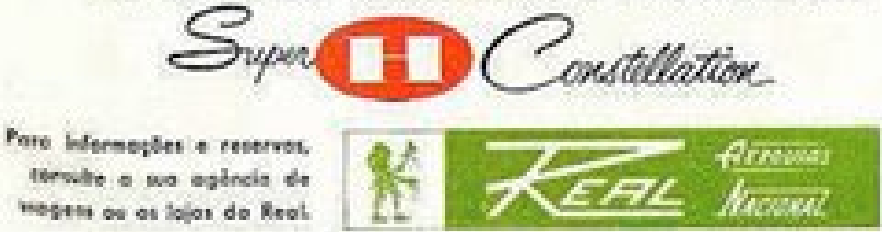

"Seu atributo [da memória] mais imediato é garantir a continuidade do tempo e permitir resistir à alteridade, ao 'tempo que muda', as rupturas que são o destino de toda vida humana; em suma, ela constitui - eis uma banalidade - um elemento essencial da identidade, da percepção de si e dos outros". (ROUSSO, 2001, p.94-95)

Quando der o meio-dia, chegarão as crianças do colégio, o marido do trabalho, todos famintos, todos gulosos pelos pratos que a senhora preparou e que começam - lágrimas - no ritual este de cortar cebolas. A senhora, Dona Eugênia, a senhora nem se importa, a senhora faz que não sabe, a senhora sempre repete que gosta que se sentem e que comam. A senhora gosta que eles mastiguem em silêncio, que devorem num zás o que lhe tomou tanto tempo. Os filhos bons, crescidos, o marido bom, amoroso.
Escrever um ensaio é muito mais de que apenas descrever situações ou narrar fatos, é expressar seus próprios sentimentos, pensamentos, opiniões. Tudo aquilo que passar pela sua mente e desejar ser expresso em palavras e impresso numa folha de papel.

\section{“... a necessidade de o historiador misturar relato $\mathrm{e}$ explicação fez da história um gênero literário, uma arte..." (LE GOFF, 1992, p. 12)}

Mnemosine lembrava aos homens a recordação dos heróis e dos seus grandes feitos, preside a poesia lírica. Deste modo, o poeta era um homem possuído pela memória, um adivinho do passado, a testemunha inspirada nos "tempos antigos", da idade heroica e, por isso, da idade das origens.

Mnemosyne (1881),

Dante Gabriel Rossetti
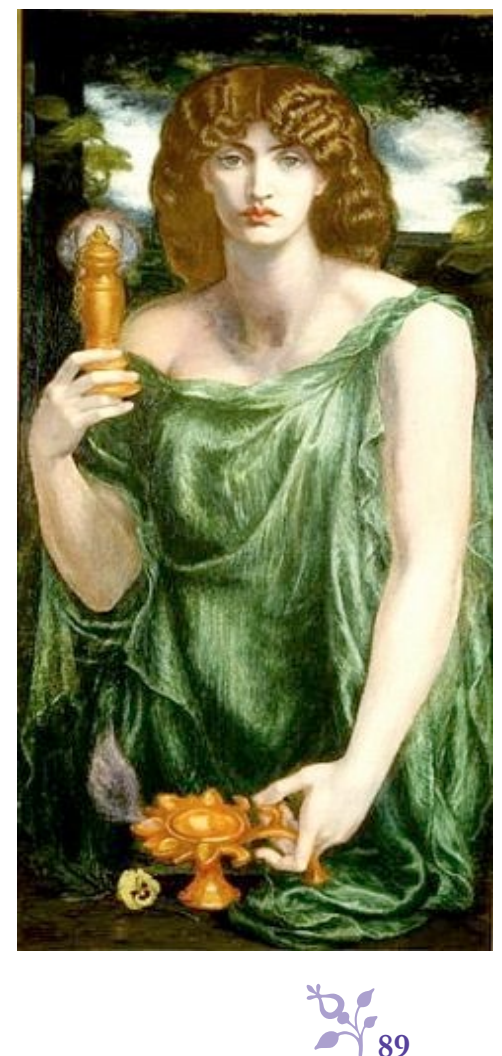
A senhora não percebe, as outras mulheres tampouco percebem, que o cheiro das cebolas se perpetua debaixo das unhas, encravado na pele, colado aos cabelos, junto com o cheiro do sabonete, do xampu, do creme, do perfume. Cheiro de mulher.

Suportou dois anos de purgatório: sem cabelos, com a boca altamente atingida e proibida de fumar, vício de mais de três décadas e meia. "Veio o gosto de sangue na boca, e não era meu, era de meu pai, que morreu de câncer. Latejava em minha cabeça: câncer, câncer!' Seu pai, Elias, sofreu um câncer de pâncreas e faleceu em seguida, em 1979, aos 56 anos. Foi a pior cena de sua memóría. Uma coincíếncia terrivel de entender. "Levamos para São Paulo, permaneceu duas semanas em coma, mas não superou. Meu imortal morreu."

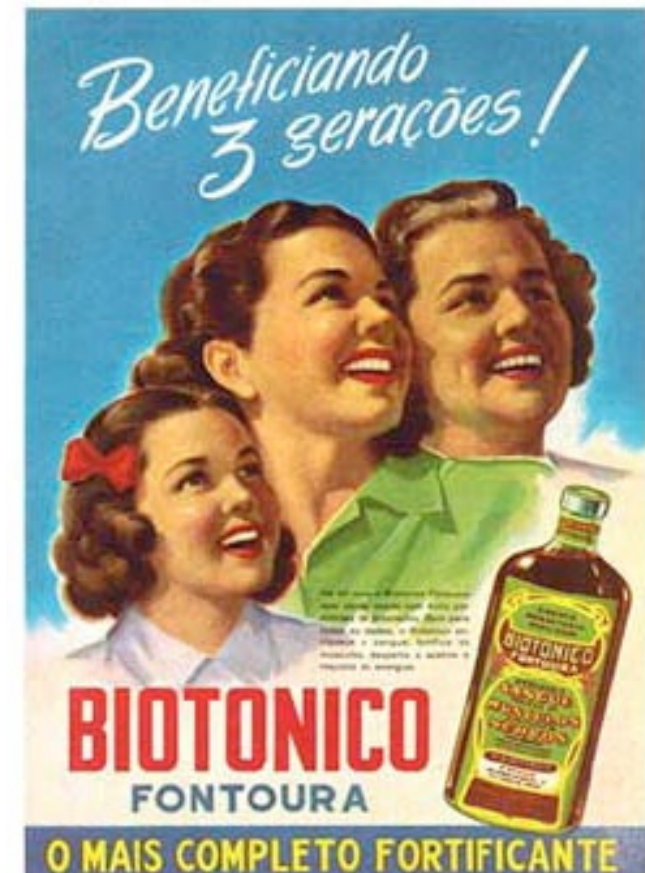

"À medida que um gênero faz-se familiar a um público de leitores, o autor tem menos necessidade de colocar sinais no interior do seu texto para certificar-se de que ele será lido como convém." (MIRANDA, 1992, p. 32)

A outra história é a primeira mesmo e chama-se "O assassinato". Começa assim: queixei-me de baratas. Uma senhora ouviu-me. Segue-se a receita. E então entra o assassinato. A verdade é que só em abstrato me havia queixado de baratas, que nem minhas eram: pertenciam ao andar térreo e escalavam os canos do edifício até o nosso lar. Só na hora de preparar a mistura é que elas se tornaram minhas também. Em nosso nome, então, comecei a medir e pesar ingredientes numa concentração um pouco mais intensa. Um vago rancor me tomara, um senso de ultraje. De dia as baratas eram invisíveis e ninguém acreditaria no mal secreto que roia casa tão tranquila. Mas se elas, como os males secretos, dormiam de dia, ali estava eu a preparar-lhes o veneno da noite. Meticulosa, ardente, eu aviava o elixir da longa morte. Um medo excitado e meu próprio mal secreto me guiavam. Agora eu só queria gelidamente uma coisa: matar cada barata que existe. Baratas sobem pelos canos enquanto a gente, cansada, sonha. $E$ eis que a receita estava pronta, tão branca. Como para baratas espertas como eu, espalhei habilmente o pó até que este mais parecia fazer parte da natureza. 


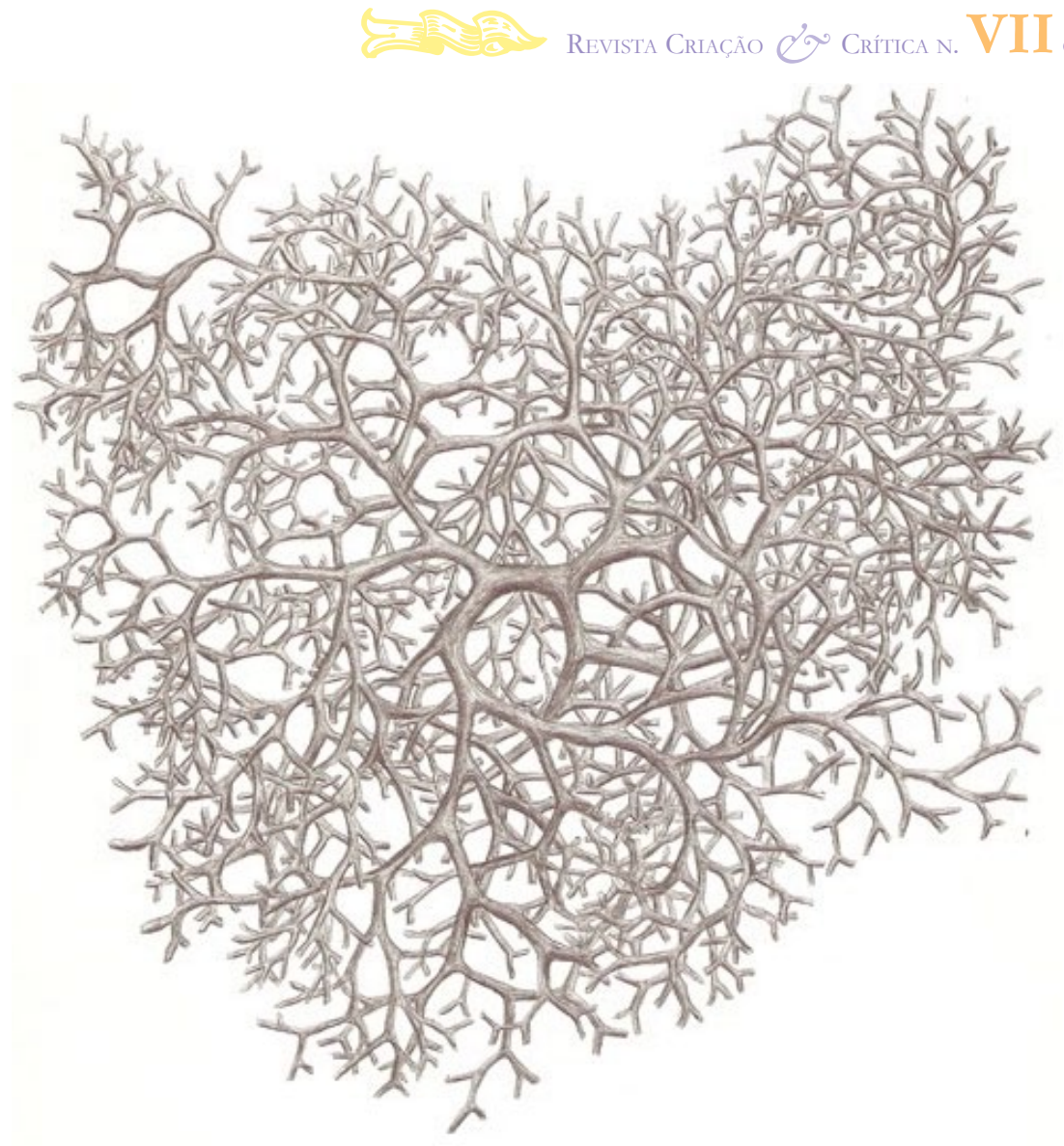

Devir é jamais imitar, nem fazer como, nem ajustar-se a um modelo, seja ele de justiça ou de verdade. Não há um termo de onde se parte, nem um ao qual se chega ou se deve chegar. Tampouco dois termos que se tocam. A questão "o que você está se tornando?" é particularmente estúpida. Pois à medida que alguém se torna, o que ele se torna muda tanto quanto ele próprio. Os devires não são fenômenos de imitação, nem de assimilação, mas de dupla captura, de evolução não paralela, núpcias entre dois reinos. (Deleuze \& Parnet, 1998, p.10)

De minha cama, no silêncio do apartamento, eu as imaginava subindo uma a uma até a área de serviço onde o escuro dormia, só uma toalha alerta no varal. Acordei horas depois em sobressalto de atraso. Já era de madrugada. Atravessei a cozinha. No chão da área lá estavam elas, duras, grandes. Durante a noite eu matara. Em nosso nome, amanhecia. No morro um galo cantou.
Rizoma - Rizoma é um modelo descritivo ou epistemológico proposto por Gilles Deleuze e Félix Guattari. Neste modelo epistemológico, a organização dos elementos não segue linhas de subordinação hierárquica - com uma base ou raiz dando origem a múltiplos ramos -, mas, pelo contrário, qualquer elemento pode afetar ou incidir em qualquer outro.

A noção de rizoma foi adotada da estrutura de algumas plantas que se ramificam em qualquer ponto, assim como se engrossam e se transformam num bolbo ou tubérculo; o rizoma da botânica, que tanto pode funcionar como raiz, talo ou ramo, independente de sua localização na figura da planta, serve para exemplificar um sistema epistemológico onde não há raízes - ou seja, proposições ou afirmações mais fundamentais do que outras - que se ramifiquem segundo dicotomias estritas.

O modelo rizomático presta-se a mostrar que a estrutura convencional das disciplinas epistemológicas não reflete simplesmente a estrutura da natureza, mas sim que é um resultado da distribuição de poder e autoridade no corpo social. A organização rizomática do conhecimento é um método para resistir a um modelo hierárquico que reflete, na epistemologia, uma estrutura social opressiva. 
As diferentes leituras constroem uma "cadeia de recepções" que decidirá a importância da obra e indicará sua posição na hierarquia estética. As obras desfamiliarizantes, subversivas - escriptíveis - podem ser tornar consumíveis, clássicas ou até "culinárias" - legíveis para as futuras gerações, segundo Roland Barthes. Por isso é necessário lêlas de trás para frente, ou ao revés, a fim de restabelecer a leitura dos primeiros leitores e os seguintes, para restaurar sua diferença.

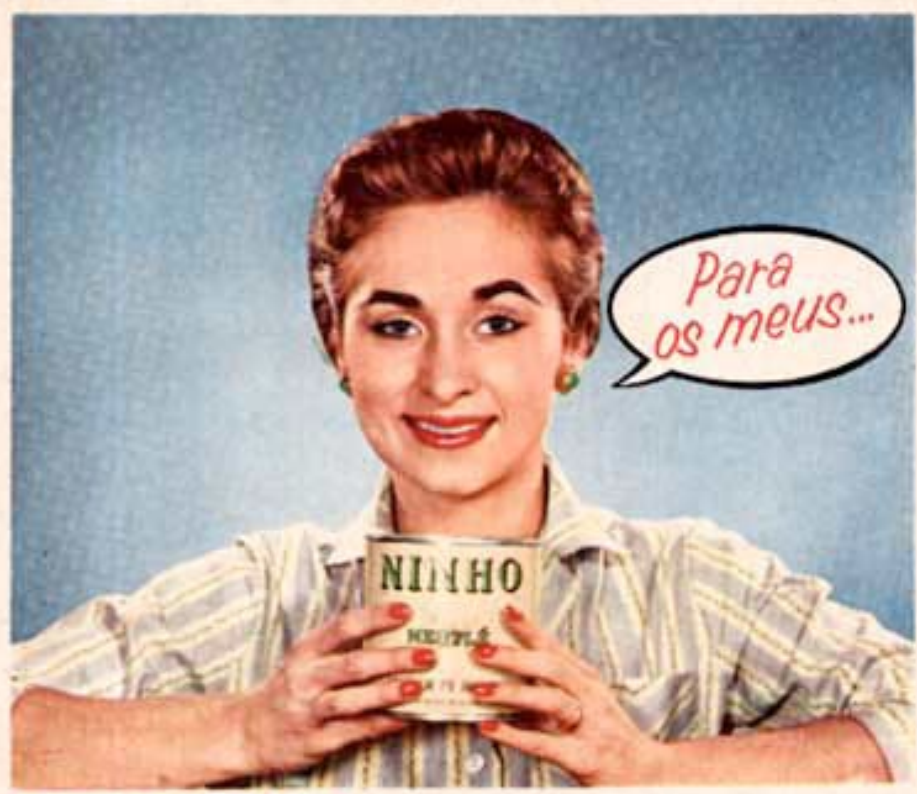

\section{LEITE NINHO - o melhor do mundo!}

Ninhe 6 fobrieade com leite de ordentha resente e de 1,* qualidade. Quando V. toma o seu copo de leite Ninho pode ter a certera de obtido de vacas que vivern ao ar livre, ali. mentando-se de ricas pastagens.

Ninhe 6 sempre treseo porque seus estoques sio constantemente renovados, graças ao seu grande consumo.

Dige V. tomberm; para os movs... Leite Ninhol

LEITE NINHO- o melhor!

A vende em tíde parte, em later do

$454,1.000 \cdot 2.000$ g (piso liquido)

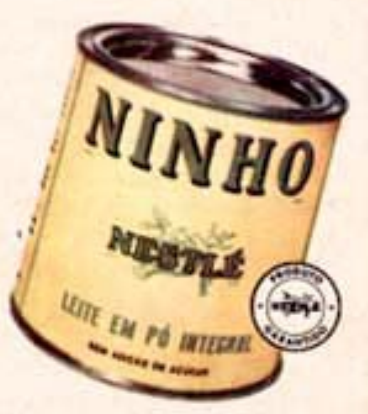

Mas, amanhã, as coisas vão ser diferentes. Amanhã a nora, a casada com o filho mais velho, vai pedir que a senhora cuide do nenê, a babá não vai poder, a creche não vai se saber bem o quê. Vai ficar lá na sala o pimpolho, ele que já começou a engatinhar, e quando a senhora, Dona Eugênia, estiver com tudo pronto para começar a tarefa universal e perpetuadora, ali as cebolas, a tábua e a faca, o netinho vai lhe puxar pela barra da saia, ele que vai vir até a cozinha se arrastando pelo chão, no universo térreo das crianças.

"A tarefa de retratar-se e avaliar-se do autobiógrafo é, evidentemente, o aspecto essencial da questão, embora o modo como o autor organiza o seu texto e os processos narrativos que emprega sejam, com frequência, motivo de interesse para o leitor." (MIRANDA, 1992, p. 32) 
Naquele 2 de setembro em que recebeu o veredicto, Cintía Moscovich encontrou uma coragem nas lembranças paternas. "O pai era um homem que as pessoas, de forma desavisada, chamariam de sisudo. Mas, quando ria, sua rísada íluminava o rosto como se todos os traços de luz do mundo se refletissem em seus dentes e olhos.

Lembro, como se fosse hoje, do pai fazendo a barba. Fle me colocava sentadinha ali, junto com ele, num banquinho do lado da pia, e perguntava: 'Como é que faz a galinha? $\mathcal{E}$ a vaquinha? $\mathcal{E}$ o cachorrinho?' Eu respondia, feliz da vida, porque sabia que meía dúzia de au-aus e cocoricós faría com que ele não resistisse e, dando rísadas, ia me pegar no colo e me encher de beijos: eu era amada. Meu pai me ensinou a rir e a amar sem condiçôes."

Não, a senhora não poderá evitar, a senhora tomará o pequeno nos braços e o levará até a sala, falando a linguagem dele, aquela de sílabas repetidas, que a senhora, Dona Eugênia, gosta de pensar que é a única que ele entende e que é a que a senhora fala melhor. A senhora vai se ajoelhar no chão, vai ficar de quatro, vai fazer caretas e ele vai se finar de tanto rir. A senhora vai imitar cachorrinho, porquinho, galinha, vaquinha, passarinho, e ele vai tentar imitar a senhora, a mãozinha gorducha no ar. A senhora vai surrupiar o lençol da cama e vai fazer uma cabana para que vocês possam brincar de índio, e ele vai cair de bunda, ploft amaciado pelas fraldas, arreganhando os dois dentinhos que recém agora lhe saíram.

A terceira história que ora se inicia é a das "Estátuas". Começa dizendo que eu me queixara de baratas. Depois vem a mesma senhora. Vai indo até o ponto em que, de madrugada, acordo e ainda sonolenta atravesso a cozinha. Mais sonolenta que eu está a área na sua perspectiva de ladrilhos. $\mathrm{E}$ na escuridão da aurora,um arroxeado que distancia tudo, distingo a meus pés sombras e brancuras: dezenas de estátuas se espalham rígidas. As baratas que haviam endurecido de dentro para fora. Algumas de barriga para cima. Outras no meio de um gesto que não se completaria jamais. Na boca de umas um pouco da comida branca. Sou a primeira testemunha do alvorecer em Pompeia. Sei como foi esta última noite, sei da orgia no escuro. 
Daí, Dona Eugênia, a senhora vai descobrir. E, na plenitude da descoberta, que se dane o reino das cebolas e o arroz e o refogado e a carne, a comida, a que sempre veio da senhora, dia depois de dia. O caminho vai estar invertido, esse que ia da teta ao fogão. Os filhos, ao chegarem, ficarão embasbacados com a mãe de quatro no tapete e com as panelas vazias. $\mathrm{O}$ marido, Dona Eugênia, vai tentar entender e contornar o imprevisto com um arreglo qualquer, desajeitado, ele que nunca vai cheirar a cebola. Ele que nunca vai ter reino nenhum.
A autobiografia "só existe enquanto parte das instituições sociais e literárias que a criam e sustentam, podendo ser afetada por mudanças que atingem uma sociedade inteira ou, particularmente, apenas o sistema literário. A autobiografia apropriou-se, ao longo do seu desenvolvimento, de diversos procedimentos formais de outros tipos de discurso." (MIRANDA, 1992, p. 32)

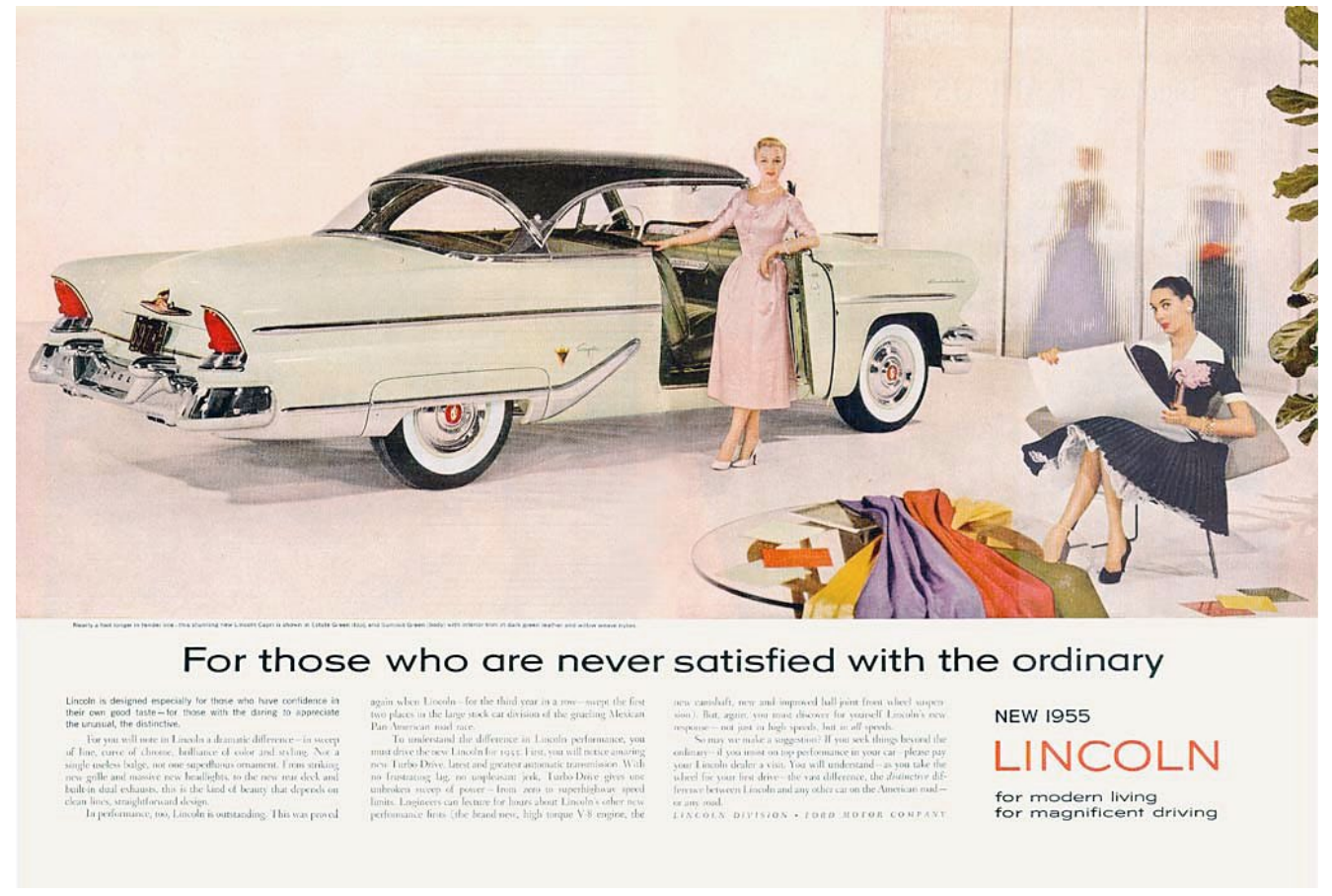

O devir-animal, afirmam Deleuze e Guattari (1997, p. 12) em Mil Platôs, "não se contenta em passar pela semelhança" e constitui uma "irresistível desterritorialização". Está no "entre-lugar", no "meio", no por vir. Em a Lógica do sentido Deleuze fala do devir-louco, devir ilimitado, devir subversivo, capaz de reverter o platonismo, romper com o binarismo que opõe elementos que se complementam e não se repelem como fundamentou Platão. 


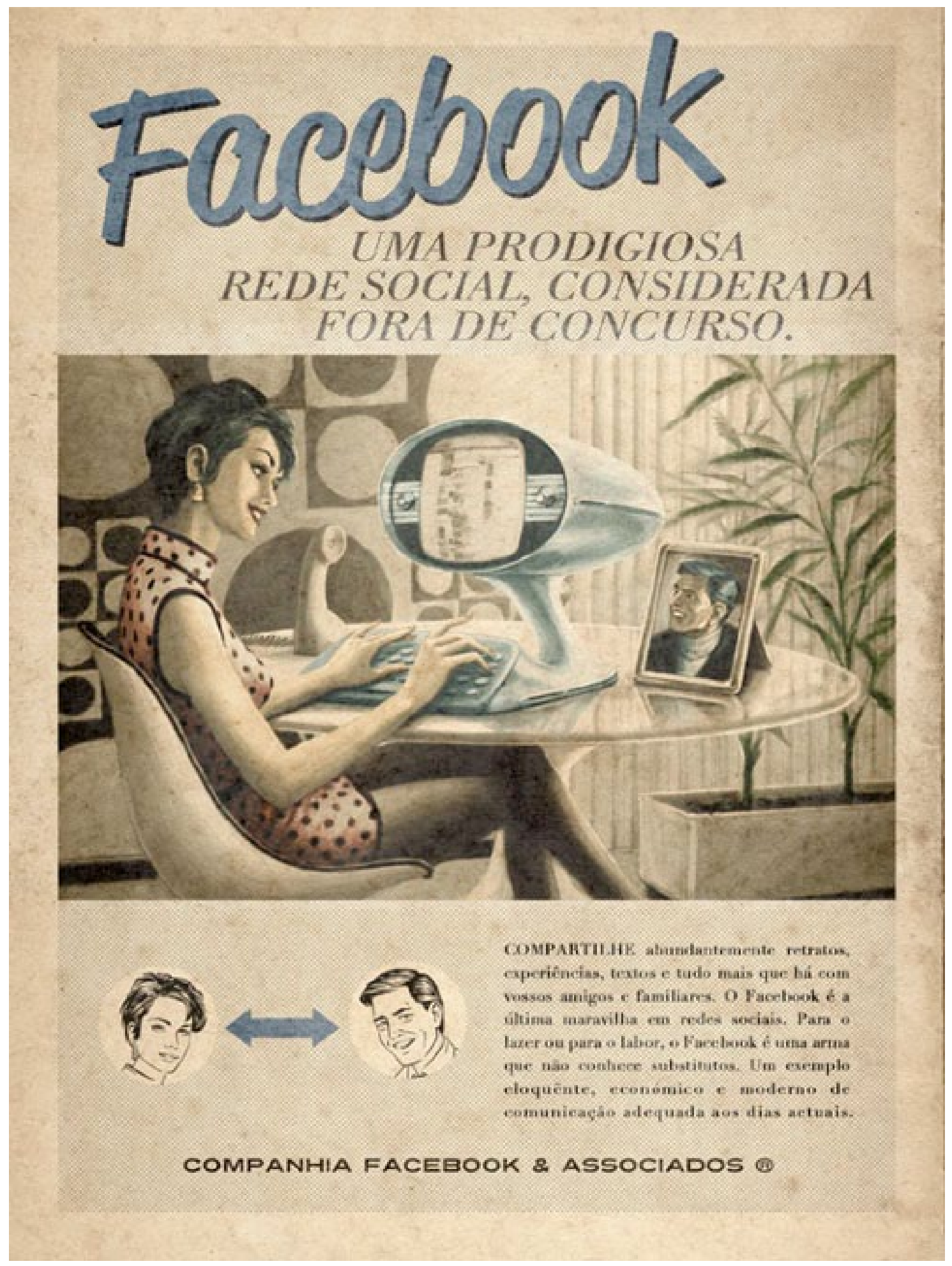

O simulacro não é uma cópia degradada, ele encerra uma potência positiva que nega tanto o original como a cópia, tanto o modelo como a reprodução. Pelo menos de duas séries divergentes interiorizadas no simulacro, nenhuma pode ser designada como o original, nenhuma como a cópia. Não basta nem mesmo invocar um modelo do Outro, pois nenhum modelo resiste à vertigem do simulacro. (Deleuze, 1998, pp. 267-268) 


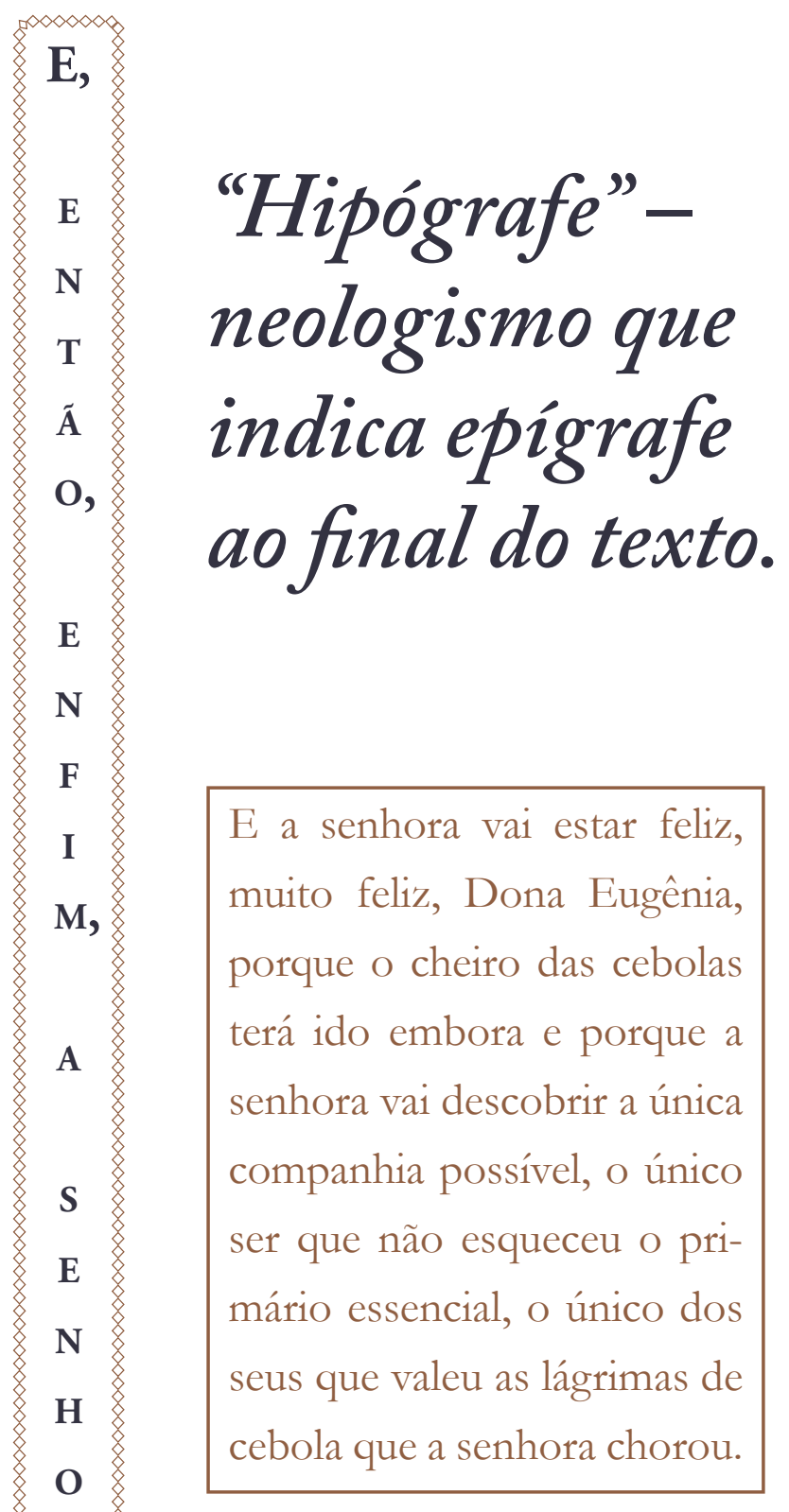

$\mathbf{R}$

A

V

A

I

$S$

A

B

E

R.

\section{A quarta narrativa} inaugura nova era no lar. Começa como se sabe: queixei-me de baratas. Vai até o momento em que vejo os monumentos de gesso. Mortas, sim. Mas olho para os canos, por onde esta mesma noite renovar-se-á uma população lenta e viva em fila indiana.

Em algumas o gesso terá endurecido tão lentamente como num processo vital, e elas, com movimentos cada vez mais penosos, terão sofregamente intensificado as alegrias da noite, tentando fugir de dentro de si mesmas. Até que de pedra se tornam, em espanto de inocência, e com tal, tal olhar de censura magoada. Outras - subitamente assaltadas pelo próprio âmago, sem nem sequer ter tido a intuição de um molde interno que se petrificava! — essas de súbito se cristalizam, assim como a palavra é cortada da boca: eu te... Elas que, usando o nome de amor em vão, na noite de verão cantavam. Enquanto aquela ali, a de antena marrom suja de branco, terá adivinhado tarde demais que se mumificara exatamente por não ter sabido usar as coisas com a graça gratuita do em vão: "é que olhei demais para dentro de mim! é que olhei demais para dentro de..." - de minha fria altura de gente olho a derrocada de um mundo. Amanhece. Uma ou outra antena de barata morta freme seca à brisa. Da história anterior canta o galo.

Não se obrigando à coerência sistemática, o discurso ensaístico sabe recorrer à imagem e à metáfora, tira partido do movimento digressivo, percorre diferentes campos de saber, fugindo à compartimentalização e à especialização disciplinar. Sem abrir mão do trabalho com o conceito - o que o distingue, afinal, da poesia e da arte em geral - ele vai reconhecer sua mediatez, sua condição de linguagem e vai se propor a fazer dele um uso imediato. Em outras palavras, vai se apropriar de conceitos originários de sistemas filosóficos e científicos os mais diversos e, libertando-os do peso dessa origem, da pureza e transcendência que ela Ihes impunha, vai vê-los funcionar e significar a partir de sua inserção numa forma discursiva nova, de sua colaboração numa experiência intelectual específica e provisória. Desse modo, foge aos padrões frios da descrição analítica e da erudição metafísica, para se definir como interpretação.

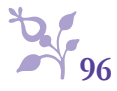


Perseguindo uma objetividade textual, estudiosos de algumas áreas do conhecimento como a teoria literária e a filosofia/teoria da história, aderiram à extinção da narração em primeira pessoa na tentativa de urdir um texto mais objetivo e impessoal. No entanto, "contemporaneamente, percebe-se que, quando o narrador se disfarça atrás de recortes e colagens, não busca objetividade, mas pluralidade. É um jogo de esconder. Ele não aparece, mas existe, está sempre lá, em cada escolha, espiando pelas fendas, visíveis ou mascaradas, entre os fragmentos", conforme Weinhardt (2001, p. 346).

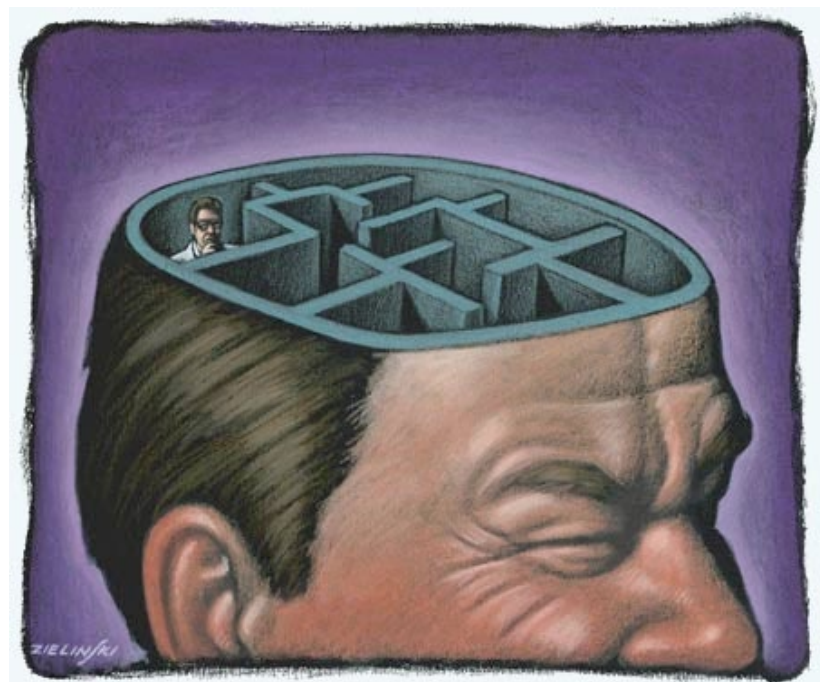

"Enquanto que os vivos podem dispor de uma memória técnica, científica e intelectual cada vez mais rica, a memória parece afastar-se dos mortos... a comemoração dos mortos entra em declínio" (LE GOFF, 1992, p. 461)

\author{
A quinta história \\ chama-se "Leibnitz e a \\ Transcendência do Amor na \\ Polinésia". Começa assim: \\ queixei-me de baratas...
}

Eu iria então renovar todas as noites o açúcar letal? - como quem já não dorme sem a avidez de um rito. $E$ todas as madrugadas me conduziria sonâmbula até o pavilhão? - no vício de ir ao encontro das estátuas que minha noite suada erguia. Estremeci de mau prazer à visão daquela vida dupla de feiticeira. E estremeci também ao aviso do gesso que seca: o vício de viver que rebentaria meu molde interno. Áspero instante de escolha entre dois caminhos que, pensava eu, se dizem "adeus", e certa de que qualquer escolha seria a do sacrifício: eu ou minha alma. Escolhi. E hoje ostento secretamente no coração uma placa de virtude: "Esta casa foi dedetizada".

Nos livros-raiz, tão valorizados pela utopia moderna da unidade, todos os argumentos são organizados em torno um eixo central e têm como função sustentar uma ideia, partindo de um ponto prefixado e usando um método bem definido. $\mathrm{O}$ paradigma do livro-raiz é a monografia acadêmica, em que tudo precisa convergir para um único ponto: sustentar a validade da hipótese inventada pelo autor. Tudo o que extrapola esse limite é sentido como supérfluo, como um excedente a ser cortado, tanto por fugir aos objetivos específicos da obra quanto para evitar os ataques de uma banca eventualmente hostil. 


\section{"Daí, pois, como já se disse, exigir a primeira leitura paciência, fundada em certeza de que, na segunda, muita coisa, ou tudo, se entenderá sob luz inteiramente outra." SCHOPENHAUER}

${ }^{1}$ Para Igor, por me ajudar a empurrar a bicicleta enferrujada!

\section{Webgrafia}

Sobre o ensaio p. 1 e 2 - Dicionário do termos literários - http://www.fcsh.unl.pt/invest/edtl/ verbetes/E/ensaio.htm

Sobre o ensaio - BURKE, Peter. In: http://www.folhanet.com.br/portasdasletras/ ensaio.html

Sobre o rizoma - http://pt.wikipedia.org/wiki/Rizoma_\%28filosofia\%29

Entrevista com Cíntia Moscovich - Disponível em: http://contigo.abril.com.br/noticias/ gente-historias-cintia-moscovich-567138

Blog de Cíntia Moscovich - http:/ /www.cintiamoscovich.com/blog/

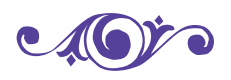

\section{Referencias OBibliagraificas}

DELEUZE, Gilles. Crítica e clínica. São Paulo: Ed. 34, 1997.

. Lógica do sentido. 4a . Ed. São Paulo: Perspectiva, 1998.

DELEUZE. G.; GUATTARI, F. Mil Platôs: capitalismo e esquizofrenia. São Paulo: Ed. 34, 1997, volume 04 .

DELEUZE, Gilles; PARNET, Claire. Diálogos. São Paulo: Escuta, 1998.

DELL'ISOLA, Regina L. P. Ensaios em arte final. Belo Horizonte: UFMG, 2002.

ECO, Umberto. Sobre os espelhos e outros ensaios. Rio de Janeiro: Nova Fronteira, 1989, p. 100.

LE GOFF, Jacques. História e Memória. Campinas: Ed. UNICAMP, 1992.

MIRANDA, Wander de Melo. Corpos escritos: Graciliano Ramos e Silviano Santiago. São Paulo:

Edusp/Belo Horizonte: UFMG, 1992.

MOSCOVICH, Cínta. O Reino das Cebolas. Porto Alegre: L\&PM, 2002.

ROSA, João Guimarães. Tutaméia: terceiras estórias. $6^{2}$ edição. Rio de Janeiro: Nova Fronteira, 1985.

ROUSSO, Henry. A memória não é mais o que era. In: FERREIRA, Marieta de Moraes; AMADO,

Janaína (Org.). Usos e abusos da história oral. 4. ed. Rio de Janeiro: FGV, 2001.

SANTIAGO, Silviano. O narrador pós-moderno. In: . Nas malhas da letra. São Paulo:

Companhia das Letras, 1989.

WEINHARDT, M. As vozes documentais no discurso romanesco. In FARACO, C. et al. Diálogos com

Bakbtin. $3^{a}$ ed. Curitiba: Editora da UFPR, 2001. 